\title{
Measurements of Wet Canopy Evaporation in Forests: A Review
}

\author{
Hyojung Kwon* \\ National Center for Agro-Meteorology, Seoul National University, Seoul 151-742, Korea
}

\section{산림에서의 젖은 군락 증발 관측: 고찰}

\author{
권 효 정* \\ (재)국가농림기상센터
}

\begin{abstract}
Wet canopy evaporation $\left(E_{W C}\right)$ has been recognized as a significant component of total evapotranspiration, especially in forests and therefore it is critical to accurately assess $E_{W C}$ to understand forest hydrological cycle. In this review, I focused on the measurement methods and evaluating the magnitudes of $E_{W C}$ at diverse forest types (e.g., deciduous, coniferous, mixed, and rain forests). I also present the general issues to be considered for $E_{W C}$ measurements. The commonly used measurement methods for $E_{W C}$ include the water balance, energy balance, and the Penman-Monteith (PM) methods. The magnitudes of $E_{W C}$ ranged from 5 to $54 \%$ of precipitation based on the literature review, showing a large variation even for a similar forest type possibly related to canopy structure, rainfall intensity, and other meteorological conditions. Therefore, it is difficult to draw a general conclusion on the contribution of $E_{W C}$ to evapotranspiration from a particular forest type. Errors can arise from the measurements of precipitation (due to varying wind effect) and throughfall (due to spatial variability caused by canopy structure) for water balance method, the measurements of sensible heat flux and heat storage for energy balance method, and the estimation of aerodynamic conductance and unaccounted sensible heat advection for the PM method. For a reliable estimation of $E_{W C}$, the combination of ecohydrological and micrometeorological methods is recommended.
\end{abstract}

Kew words : Evaporation, Wet canopy, Water balance, Energy balance, Penman-Monteith, Forest

\section{INTRODUCTION}

Evapotranspiration $(E T)$ interconnects energy, water, and carbon cycles in terrestrial ecosystems. ET is the sum of transpiration, soil evaporation, and canopy evaporation and the quantitative estimation of each component is important for the process-based understanding of hydrological cycle.

During rainy periods, a portion of rainfall is intercepted by the vegetation canopy and evaporates back to the atmosphere (defined as wet canopy evaporation or interception loss; Fig. 1). Wet canopy evaporation $\left(E_{W C}\right)$ has been recognized as a significant contributor to $E T$. Variation of the $E_{W C}$ magnitude is associated with forest structure, distribution and intensity of rainfall, and climate conditions (Pypker et al., 2005; Herbst et al., 2008; Sraj et al., 2008). Since radiation is low during rainy period, $E_{W C}$ is mainly determined by aerodynamic conductance and the available energy, indicating that $E_{W C}$ is fundamentally physical rather than biological. Forests, which have higher aerodynamic conductance and heat storage, have much higher rates of $E_{W C}$ than short vegetation and thus most interception studies have focused on forest areas (Stewart, 1977; Dingman, 


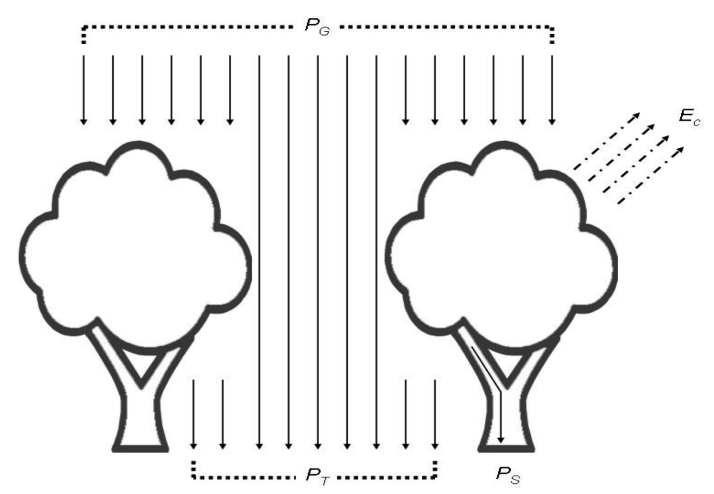

Fig. 1. Canopy interception loss. $\left(P_{G}\right.$ is gross fall, $P_{T}$ is throughfall, $P_{S}$ is stemflow, and $E_{W C}$ is canopy interception loss)

2002).

Annual $E_{W C}$ ranges from 10 to $40 \%$ of total precipitation in various plant communities (Dingman, 2002). Other earlier studies reported that $E_{W C}$ ranged from 25 to $50 \%$ in coniferous forest (Rutter et al., 1975; Gash et al., 1980; Johnson, 1990) and from 10 to $28 \%$ in broadleaved forests (Rutter et al., 1975; Sraj et al., 2008). Considering the reported magnitude of $E_{W C}, E_{W C}$ is one of the major hydrological processes that alter the quantity, timing, and distribution of water input and output in forested areas. Therefore, an accurate assessment of $E_{W C}$ is critical in understanding of the forest hydrological cycle.

$E_{W C}$ has been commonly measured by water balance (i.e., the difference between gross rainfall and the sum of throughfall and stemflow; Horton, 1919; Rutter et al., 1975; Valente et al., 1997). Energy balance method (i.e., the difference between net radiation and the sum of sensible heat, ground heat, and energy storage) is another approach to measure $E_{W C}$. In this approach, the Bowen ratio, eddy covariance, and temperature variance techniques have been applied (Gash et al., 1999; Schellenkens et al., 2000). The estimation of $E_{W C}$ is also conducted using the Penman-Monteith combination equation by assuming that surface conductance is negligible. Rutter et al. (1975) was the first to estimate $E_{W C}$ in forest using this method. Due to the shortcomings of each method, a combination of multiple methods is often used to improve the validity of the measurement (e.g., Gash et al., 1999).

Studies on $E_{W C}$ have been reviewed and the most recent examples are Crockford and Richardson (2000), Dunkerley (2000), and Llorens and Domingo (2007).
They reviewed the studies on $E_{W C}$ mostly conducted by water balance method, focusing on the effect of forest types, ground cover, and climate on $E_{W C}$ at various locations. Other methods of $E_{W C}$ measurements have not been reviewed in these papers.

Despite the importance of $E_{W C}$ in the hydrological cycle in the forested areas, which occupy approximately $65 \%$ of the total land area in Korea, little attention has been paid to the role of $E_{W C}$. Domestic researches on $E_{W C}$ have been rare and several attempts have been made to measure $E_{W C}$ by using water balance method (Kim and Woo, 1988; Min and Woo, 1995; Lee et al., 1997; Kim et al., 2005). Recently in Korea, the eddy covariance technique has been employed to measure $E_{W C}$ simultaneously with the measurement of leaf wetness at multiple levels in deciduous and coniferous forests (Kang et al., 2011).

In view of the proceedings, a general review is provided on the measurement methods and the reported magnitudes of $E_{W C}$ in different forest types. In this review, I introduce the results of the studies on $E_{W C}$ in various forest types and the diversity of the measurement techniques and to highlight the challenges and issues associated with each technique based on case studies.

\section{MEASUREMENT TECHNIQUES}

\subsection{Determination of canopy wetness}

Determination of wet canopy is important to differentiate canopy evaporation from evapotranspiration. Based on the literature review, three methods are suggested to determine whether a canopy is wet or not.

\subsubsection{Precipitation intensity}

Gash (1979) defined the period with more than 0.5 $\mathrm{mm} / \mathrm{hr}$ of rain as wet canopy condition by assuming the canopy being saturated.

\subsubsection{Wetness sensor}

Stewart (1977) used wetness sensors to determine the canopy condition. He installed six wetness sensors in the forest canopy space at $45^{\circ}$ to the horizontal plane to prevent standing water. If some of the wetness sensors indicate wetness, the canopy is defined as "partly" wet. If all the wetness sensors indicate that water is lying on the sensors, the canopy was described as "completely" wet. $E_{W C}$ is then calculated when the canopy is completely wet. 


\subsubsection{Surface conductance}

Stewart (1977) used surface conductance calculated from the Penman-Monteith equation (Eq. 1) as an indicator of canopy saturation status when surface conductance is within the range of 0 to $10 \mathrm{~s} \mathrm{~m}^{-1}$.

\subsection{Estimation of wet canopy evaporation}

\subsubsection{Penman-monteith method}

Wet canopy evaporation $\left(E_{W C}\right)$ can be estimated using the Penman-Monteith (PM) equation (Monteith, 1965).

$$
E=\frac{1}{\lambda} \frac{\Delta A+\rho C_{p}\left(e_{s}-e_{a}\right) g_{a}}{\Delta+\chi\left(1+g_{a} / g_{s}\right)}
$$

where 1 is the latent heat of vaporization of water, $A$ (= $R_{N}-G-S$ ) is the available energy (here $R_{N}$ is the net radiation, $G$ is ground heat flux, and $S$ is the heat storage between the measurement height and ground level), $\rho$ is the air density, $C_{p}$ is the specific heat of air, $e_{s}$ is saturated vapor pressure, $e_{a}$ is actual vapor pressure, $g_{a}$ is the aerodynamic conductance, $g_{s}$ is the surface conductance, $\Delta$ is the slope of vapor pressure curve, and $\gamma$ is the psychrometric constant. When canopy is fully saturated, surface conductance is assumed to be negligible (i.e., $g_{s} \approx \infty$ ). Eq. 1 is then simplified to:

$$
E_{W C}=\frac{1}{\lambda} \frac{\Delta A+\rho C_{p}\left(e_{s}-e_{a}\right) g_{a}}{\Delta+\gamma}
$$

$g_{a}$ is estimated by:

$$
g_{a}=\frac{k^{2} u}{\left(\ln (z-d)^{\prime} z_{o, M}\right)^{2}}
$$

where $k$ is the von Kármán constant, $u$ is the wind speed at height $z, d$ is the zero displacement height ( $\approx 0.75 \mathrm{hr}$, where def. of hr is the canopy height), and $z_{o . M}$ is the roughness length for momentum $(\approx 0.1 \mathrm{hr})$. Estimation of $E_{W C}$ using Eq. 2, however, is sensitive to the value of $g_{a}$ (Gash et al., 1980 and 1999) and it is critical to use the right equation to accurately present the transport of water vapor through the atmospheric surface layer (Gash et al., 1999). Gash et al. (1999) suggested several ways of calculating $g_{a}$, which take different transfer mechanisms of heat and water vapor into account.

$$
g_{a}=\frac{k^{2} u}{\ln \left((z-d) / z_{o, M}\right)\left(\ln (z-d) / z_{o, H}\right)}
$$

where $\mathrm{z}_{o . H}$ is the roughness length for heat and water vapor. When friction velocity, $u^{*}$ is measured, $g_{a}$ can be written as:

$$
g_{a}=\frac{k u^{*}}{\left(\ln (z-d)^{\left./ / z_{o, H}\right)}\right.}
$$

Following Lankreijer et al. (1993), $\ln \left(\mathrm{z}_{0, M} / \mathrm{z}_{0, H}\right)$ is taken as 2 , then

$$
\ln \left(z_{o, H}\right)=\ln \left(z_{o, M}\right)-2
$$

and Eq. 5 can be rewritten as:

$$
g_{a}=\frac{k^{2} u}{\left(\ln (z-d)^{\prime} z_{o, M}\right)+2}
$$

$g_{a}$ can be estimated only from $u$ and $u^{*}$

$$
g_{a}=\frac{u^{*}}{u^{\prime} u^{*}+2 / k}
$$

or, by following Thom (1975),

$$
g_{a}=\frac{u^{* 2}}{u}
$$

A few studies suggested to use only $\mathrm{z}_{0, H}$ to estimate $E_{W C}$ during rainfall (e.g., Klaassen et al., 1998), whereas other studies proposed to use only $\mathrm{z}_{0, M}$ (e.g., Gash et al., 1999).

\subsubsection{Water balance method}

Interception loss is the sum of canopy and ground surface interception loss. By assuming that the ground surface interception loss could be minimal compared to the canopy interception loss particularly in forest stands, the canopy interception is regarded as interception loss (i.e., wet canopy evaporation). $E_{W C}$ can be calculated as the difference between gross rainfall and net rainfall (the sum of throughfall and stemflow):

$$
E_{C}=P_{G}-P_{T}-P_{S}
$$

where $P_{G}$ is the gross rainfall, $P_{T}$ is the throughfall, and $P_{S}$ is the stemflow. Since $E_{W C}$ is the subtle balance between the two large numbers, a small fractional uncertainty in each component can generate large errors in $E_{W C}$. Application of this method contains uncertainties because of the difficulties in accurate measurement of $P_{G}$ (especially at low rainfall intensities when interception losses are relatively large), the spatial variability of $P_{T}$, and the difficulty of measuring stemflow (Dingman, 2002). The largest uncertainties stem from the measurement of $P_{G}$ during the leafless period due to higher wind speed in winter at forest sites (Herbst et al., 2008). Herbst et al. (2008) also stated that $P_{T}$ measurement can be problematic under the leafed canopy due to a large spatial variability and higher rainfall intensi- 
ties specially in deciduous forests. For coniferous forests, such spatial variability is often lower and the structural parameters hardly change during the season and thus the measurement of $P_{T}$ can be less problematic than for deciduous forests.

\subsubsection{Energy budget method}

Energy budget equation is as follow:

$$
R_{N}=H+\lambda E+G+S+P
$$

where $H$ is the sensible heat flux and $P$ is the energy absorption by photosynthesis and respiration. Because the amount of $P$ is negligible, $P$ can be ignored in Eq. 11 . By assuming that $\lambda \mathrm{E} \approx E_{W C}$ when the canopy is wet, Eq. 11 can be rewritten as:

$$
E_{W C}=\frac{1}{\lambda}\left(R_{N}-H-G-S\right)
$$

Another approach to estimate $E_{w c}$ is to use the concept of the Bowen ratio $\left(\beta=\mathrm{H} / \lambda \mathrm{E}=\left(C_{p} \partial \theta / \partial z\right) /\left(\lambda \partial q^{\prime}(1+\beta)\right)\right.$, where $\partial \theta / \partial z$ and $\partial q / \partial z$ are the gradients of potential temperature and specific humidity against height $\mathrm{z}$ ). Substituting $\beta$ in Eq. 12, Eq. 12 becomes

$$
E_{C}=\frac{1}{\lambda} \frac{A}{(1+\beta)}
$$

Most of errors in the Bowen ratio are associated with the errors in the measurements of the small temperature and humidity gradients during the rainy days.

In order to measure $H$ during the rainy period, temperature variance and eddy covariance methods are frequently used. Temperature variance method evaluates $H$ from the standard deviation of temperature fluctuations (e.g., Schellenkens et al., 2000) using the following equation (Tillman, 1972):

$$
H=\rho C_{p}\left[\left(\frac{\sigma_{T}}{C_{1}}\right)^{3}\left(k g \frac{z}{T}\right) \frac{\left(1-C_{2} \frac{z}{L}\right)}{-\frac{z}{L}}\right]
$$

where $\sigma_{T}$ is the standard deviation of temperature, $g$ is the gravity acceleration, $T$ is the air temperature, $z / L$ is the stability parameter, and $C_{1}$ and $C_{2}$ are the empirical constants (2.9 and 28.4, respectively; De Bruin et al., 1993). Under unstable atmospheric condition, $z / L$ equals the Richardson number and Eq. 14 can be simplified to (Vugts et al., 1993)

$$
H=1.075 \rho C_{p} \sigma_{T}^{3 / 2}\left(\frac{k g z}{T}\right)^{1 / 2}
$$

Eddy covariance method estimates $H$ from covariance between vertical wind velocity and temperature fluctuations by averaging these variables over any desired averaging time:

$$
H=\rho C_{p} \overline{w^{\prime} T^{\prime}}
$$

where $w$ is the vertical wind velocity. Instrument measuring temperature fluctuation is sensitive to water drop, which can cause malfunction of the instrument and generate unreliable data. Therefore, it is necessary to evaluate reliability of data obtained from the eddy covariance instrument for possible malfunction due to water.

\section{CASE STUDIES}

\subsection{Coniferous forest}

Rutter et al. (1975) calculated $E_{W C}$ for coniferous forest (Corsican pine, Pinus nigra and Douglas fir, Pseudotsuga menziesii at Bramshill forest, Hamsphire in England; Norway spruce, Picea abies at Bagely wood, Oxford in England) using the water balance method for periods from 8 to 18 months. $P_{G}$ was measured, while $P_{T}$ and $P_{S}$ were calculated by considering the canopy gap fraction and the proportion intercepted by trunks. The results showed that monthly mean values of $E_{W C}$ was $23 \mathrm{~mm} \mathrm{mon}^{-1}$ for Corsican pine and 25 $\mathrm{mm} \mathrm{mon}{ }^{-1}$ for Douglas fir with $65.3 \mathrm{~mm}$ of monthly mean precipitation and $\sim 14 \mathrm{~mm} \mathrm{mon}{ }^{-1}$ for Norway spruce with $29.8 \mathrm{~mm}$ of monthly mean precipitation. At the coniferous forests, the monthly mean $E_{W C}$ constituted 36 to $48 \%$ of the monthly mean precipitation.

The measurements of $E_{W C}$ were conducted at a pine forest (a mixture of Scots and Corsican pine; Pinus sylvestris L. and Pinus nigra var. Maritima) in Thetford Forest, England using micrometeorological (i.e., the Bowen ratio) method from March to October in 1972 and 1973 (Stewart, 1977). Transpiration and $E_{W C}$ were differentiated based on wetness conditions determined from six wetness sensors, which were installed within the forest canopy. When $A$ was greater than $20 \mathrm{~W} \mathrm{~m}^{-2}$ and the canopy was completely wet during the study period, $E_{W C}$ was calculated from Eq. 13. The calculated $E_{W C}$ was filtered again using a criterion of $g_{s}$ (i.e., -10 to $10 \mathrm{~s} \mathrm{~m}^{-1}$ ). Annual $E_{W C}$ was $145 \mathrm{~mm}$, which was $25 \%$ of the total evapotranspiration (of $566 \mathrm{~mm}$ ). In addition to the quantification of $E_{W C}$, Stewart (1977) investigated if the rate of $E_{W C}$ exceeds the input of $A$. At the pine forest, $E_{W C}$ used $127 \%$ of $A$, which was three 
times the transpiration rate (of $41 \%$ of the available energy) that occurred when the canopy was dry under the same level of $A$. The excess $E_{W C}$, compared to $A$, indicated that additional energy was provided by a downward flux of sensible heat form the air generated from an inversion of temperature over the forest. Measurements of $E_{W C}$ were conducted over maritime pine forest (Pinus pinaster Ait.) at Pinhal de Carrasqueira in central Portugal in order to evaluate Rutter model's performance in response to the canopy closure (i.e., complete or incomplete closure) and $g_{a}$ calculation (Gash et al., 1999). The average height of trees was 20 $\mathrm{m}$ and the density was 312 stems ha $^{-1} . E_{W C}$ was estimated using two different methods (i.e., the PM method and the energy balance method). $H$ was measured using eddy covariance technique by applying a sonic anemometer (Model 1012R, Gill Instruments, Lymington, UK) and other necessary measurements (e.g., $R_{N}, G$, and $P_{G}$ ) were conducted. A power spectra analysis demonstrated that the performance of the anemometer was not affected by rainfall and thus the measurements of $H$ were reliable. Based on criteria on atmospheric saturation (either a 20 min block of eddy correlation data or a 10 min block of eddy correlation overlapping with saturated weather conditions), 34 cases, qualifying by the criteria, were selected to estimate $E_{W C} . E_{W C}$ ranged from 10 to $250 \mathrm{~W} \mathrm{~m}^{-2}$ during the 34 cases. The best agreement between the measured and estimated $E_{W C}$ was observed when a combination of using $g_{a}$ for momentum flux with incomplete canopy closure. These results assured the usage of $g_{a}$ for momentum flux and emphasized the importance of canopy structure for accurate estimation of $E_{W C}$.

Shachnovisch et al. (2008) measured $E_{W C}$ in a mature pine forest (Pinus halepensis) located in a semi-arid area on the fringes of the Negev desert of Israel. The forest density was 360 trees ha ${ }^{-1}$ with the average tree height of $10 \mathrm{~m}$. Measurements of $P_{G}, P_{T}$, and $P_{S}$ were made for three years (October 2000 to April 2003) and $E_{W C}$ was calculated using the water balance method. One rain gauge was used to measure $P_{G}$, whereas 20 rain gauges were used to measure $P_{T}$ and then the data of $P_{T}$ from each rain gauge were averaged for the final $P_{T}$ value. $P_{S}$ was monitored on six trees using collectors made from plastic rings sealed with silicone rubber. During the measurement period, $P_{G}$ varied from 306.0 to $341.5 \mathrm{~mm}$ with an average of $308.8 \mathrm{~mm}$. $P_{T}$ constituted about $94 \%$ of $P_{G}$ whereas $P_{S}$ was about $1.4 \%$ of $P_{G}$ Thus, $E_{W C}$ was about $4.6 \%$ of $P_{G}$, which was about $14 \mathrm{~mm}$ at the pine forest in semi-arid area. van der Toi et al. (2003) conducted the measurements of $E_{W C}$ in a Sitka spruce (Picea sitchensis) stand in the Hafren forest Central Wales, UK for six months (March to September, 2000). The height of the trees was about $15 \mathrm{~m}$ with the density 2,313 stems ha ${ }^{-1}$ and the canopy cover was close to $100 \%$. $H$ was measured using eddy covariance method with a sonic anemometer (Solent R3, UK) and $E_{W C}$ was calculated as a residual of the energy balance. $R_{N}$ was measured above the forest at two locations and $G$ was assumed negligible. $S$ was calculated following Herrington (1969) and Thom (1975). $E_{W C}$ was also estimated from the PM equation and vapor pressure was measured from a dry and wet bulb temperature measurements employed above the canopy. $g_{a}$ was estimated by inversely solving Eq. 9 for $g_{a} . P_{G}$ was measured outside the forest on a ground level. The canopy was considered to be wet when the amount of $P_{G}$ was more than $0.5 \mathrm{~mm}$.

The performance of the sonic anemometer was acceptable during the wet conditions, satisfying the MoninObukov similarity theory (i.e., a linear relationship between the standard deviation of vertical wind, $\sigma_{w}$ and $u^{*}$ in neutral conditionss). The average $E_{W C}$ was 0.123 $\mathrm{mm} \mathrm{hr}{ }^{-1}$, whereas the average $R_{N}$ was equivalent to $0.072 \mathrm{~mm} \mathrm{hr}^{-1}$. This indicates that the energy used for $E_{W C}$ was $70 \%$ larger than $R_{N}$. The average $P_{G}$ was 2.15 $\mathrm{mm} \mathrm{hr}{ }^{-1}$, of which only $6 \%$ was used as $E_{W C} . E_{W C}$ calculated with the PM equation was $0.090 \mathrm{~mm} \mathrm{hr}^{-1}$, which was $30 \%$ lesser than $E_{W C}$ (of $0.123 \mathrm{~mm} \mathrm{hr}^{-1}$ ) with the energy balance method. The difference was due to advection providing additional energy for $E_{W C}$ as calculated with the energy balance method but not being considered in $E_{W C}$ as calculated with the PM equation.

In order to quantify the role of $E_{W C}$, Kang et al. (2011) measured $E_{W C}$ with typical open-path eddy covariance simultaneously with leaf wetness at multiple levels in the canopy at Gwangneung coniferous forest (Abies sp.) in Korea from September 2007 to August 2008. The height of the trees was about $23 \mathrm{~m}$ with the maximum LAI of $\sim 7.5$. They defined wet canopy as the conditions when precipitation is detected and all leaf wetness sensors are wet. Due to the malfunctions of the open-path eddy covariance system, gaps in $E_{W C}$ dataset occurred and a gap-filling method (i.e., a modified-lookup table, MLT) was used to fill these gaps. They employed Variable Infiltration Capacity (VIC) land surface model (LSM) algorithm to sim- 
ulate $E_{W C}$ and to validate the gap-filled $E_{W C}$ data based on a modified-lookup table (MLT) method during wet canopy conditions. The annual $E_{W C}$ values by the MLT method was $31.9 \mathrm{~mm}$, whereas that by VIC LSM was $85.9 \mathrm{~mm}$. Overall, the annual difference was about 54 $\mathrm{mm}$, i.e. $\sim 10 \%$ of the annual ET of $530 \mathrm{~mm}$, suggesting the necessity of a separate gap-filling procedure for wet canopy conditions.

\subsection{Deciduous forest}

In deciduous hardwood forests, $P_{G}$ and $E_{W C}$ were observed and compared with the estimated $E_{W C}$ for the periods of 8 to 18 months (Rutter et al., 1975). $E_{W C}$ rate was calculated using the PM equation when the amount of water on the canopy equals or exceeds canopy storage. $E_{W C}$ was also calculated using the water balance method. $P_{T}$ and $P_{S}$ were calculated by considering the canopy gap fraction and the proportion of the intercepted by trunks, which were observed over time. The results showed that $E_{W C}$ at deciduous forest was $13 \mathrm{~mm}$ $\mathrm{mon}^{-1}$ and this magnitude was smaller than that measured simultaneously at coniferous forest (e.g., 23 to 25 $\mathrm{mm} \mathrm{mon}^{-1}$ for Corsican pine and Douglas fir and $\sim 14$ $\mathrm{mm} \mathrm{mon}^{-1}$ for Norway spruce). $E_{W C}$ constituted $20 \%$ of the total precipitation (of $65 \mathrm{~mm} \mathrm{mon}^{-1}$ ).

Herbst et al. (2008) estimated $E_{W C}$ using the water balance method and micrometeorological method (i.e., energy balance method and the PM method) in a mixed deciduous forest dominated by oak (Quercus robur L.) and birch (Betula pubescens L.) in Southern England over a period of 14 months. The average canopy height was $22 \mathrm{~m}$ and the maximum LAI was 3.9. In this study, the effect on canopy structure (i.e., leafed or leafless canopy) on $E_{W C}$ was studied. For the energy balance method, $H$ was measured from eddy covariance technique. Estimation of $G$ was conducted from the changes in soil temperature, while that of $S$ was done by calculating change in $T$ and humidity of the canopy air for the energy storage (e.g., Silberstein et al., 2001) and change in $T$ of the biomass for the energy storage in the biomass (e.g., Michiles and Gielow, 2008). The PM equation was applied to estimate $E_{W C}$ using two alternative methods of $g_{a}$ calculation following Eq. 9 and Eq. 3. For the water balance method, $P_{G}$ was collected with a funnel on top of the tower and piped down to a tipping bucket rain gauge installed on the ground level. $P_{T}$ was measured with 30 storage rain gauges employed $4 \mathrm{~m}$ apart from each other. In addition, four plastic troughs attached to automatic rain gauges were installed randomly. $P_{S}$ was collected from three oak and three birch tress from waterproof collars and connected to outlet pipes, which led to tipping bucket rain gauges. Hours with a rainfall rate more than $0.5 \mathrm{~mm}$ were considered as wet canopy condition.

The quality of $H$ measurements was assessed from the linear relationship between $\sigma_{w}$ and $u^{*}$ based on the Monin-Obukhov similarity theory. This relationship showed a reliable performance of the eddy covariance method during the wet period. $P_{G} P_{T}$, and $P_{S}$ were 773 , $564\left(73 \%\right.$ of $\left.P_{G}\right)$, and $17\left(2 \%\right.$ of $\left.P_{G}\right) \mathrm{mm}$, respectively. $E_{W C}$ was $192 \mathrm{~mm}$, which was $25 \%$ of $P_{G}$ The percentage of total $E_{W C}$ to total $P_{G}(20 \%)$ from the leafless canopy was lower than that $(29 \%)$ from the leafed canopy. However, the average rate of $E_{W C}\left(0.20 \mathrm{~mm} \mathrm{hr}^{-1}\right)$ from the leafless canopy was slightly higher than that $\left(0.19 \mathrm{~mm} \mathrm{hr}^{-1}\right)$ from the leafed canopy due to stronger wind speed and different aerodynamic properties of the leafless canopy. Unlike van de Tol et al. (2003), $E_{W C}$ from the water balance method agreed well with those from the PM equation with two alternative calculations of $g_{a}$.

$E_{W C}$ by two deciduous Mediterranean forests of contrasting stature in Slovenia was measured from May 2000 to December 2001 (Sraj et al., 2008). One forest located in the south area $\left(0.31\right.$ trees $\left.\mathrm{m}^{-2}\right)$ was denser than the other forest in the north area. The average tree height in the south area was about $8 \mathrm{~m}$, while that in the north area was about $12 \mathrm{~m}$. LAI was 6.6 for the south site and 6.9 for the north site. $P_{G}$ was measured using a tipping bucket and $P_{T}$ was measured with a combination of fixed (two gutters) and manual roving gauges (10 gauges) to provide representative samples. $P_{S}$ was made on two individual trees for the two most typical species in each site with a rubber collar fitted around each tree and a tipping bucket connected to the collar measured $P_{S}$.

During the measurement period, $P_{G}$ was $1,319 \mathrm{~mm}$ and $P_{T}, P_{S}$, and $E_{W C}$ were $67 \%, 5 \%$, and $28 \%$ of $P_{G}$ in the south area, respectively. In the north area, $P_{T}, P_{S}$, and $E_{W C}$ were $72 \%, 3 \%$, and $25 \%$ of $P_{G}(1,212 \mathrm{~mm})$, respectively. For both areas, the magnitudes of $P_{T}$ and $E_{W C}$ were strongly affected by canopy structure and rainfall intensity: $P_{T}$ was lesser and $E_{W C}$ was greater during the leaf period than the leafless period. High rainfall intensity increased $P_{T}$ but decreased $E_{W C}$ during the leaf period. Sraj et al. (2008) suggested that rainfall intensity is the most influential factor on $P_{T}$ and $E_{W C}$. On the contrary, $P_{S}$ was independent of the canopy 
structures and rainfall intensity. They also showed that wind speed strongly influenced $E_{W C}$ by shaking branches of trees and reducing the storage capacity of the canopy and thus $E_{W C}$.

Kang et al. (2011) measured $E_{W C}$ at Gwangneung deciduous forest (of Quercus sp. and Carpinus sp.) in Korea from September 2007 to August 2008 using the same method described above. The height of the trees was $\sim 18 \mathrm{~m}$ with the maximum LAI of $\sim 4.5$. The annual $E_{W C}$ values by the MLT method was $24 \mathrm{~mm}$, whereas that by VIC LSM was $57.8 \mathrm{~mm}$. Overall, the annual difference was $\sim 33.8 \mathrm{~mm}$, i.e. $\sim 10 \%$ of the annual $E T$ of $367 \mathrm{~mm}$. This magnitude was smaller than that was measured simultaneously at coniferous forest (e.g., 24 $\mathrm{mm}$ by the MLT method and $85.9 \mathrm{~mm}$ by the VIC LSM).

\subsection{Rain forest}

$E_{W C}$ was estimated from a tropical rain forest at Luquillo Experimental Forest in Puerto Rico through a combination of hydrological and micrometeorological measurements during 1996 and 1997 (Schellekens et al., 2000). The forest height was $20 \sim 25 \mathrm{~m}$ and the average LAI was between 6 and 7 with the range varying from 2 to 12 . In this study, $G$ and $S$ were assumed negligible and $R_{N}$ was estimated using a regression equation $\left(R_{N}=0.88 R_{g}-35\right.$; here $R_{g}$ is an incoming solar radiation). $P_{T}$ was recorded continuously using three steel gutters (a 180-L capacity) and from additional 20 randomly placed collectors, $P_{T}$ was also measured. $P_{S}$ was regarded as a constant $\left(2.3 \%\right.$ of $\left.P_{G}\right)$ based on the earlier study at the same site. In the PM method, $g_{a}$ was obtained by following Thom, (1975; see Eq. 12 in Schellekens et al., 2000).

$E_{W C}$, evaluated from the hydrological method, was $1,788 \mathrm{~mm}$ for 1996 and $1,364 \mathrm{~mm}$ for 1997 , accounting from 39.2 to $48.5 \%$ of $P_{G}(3,687 \mathrm{~mm}$ for 1996 and $3,480 \mathrm{~mm}$ for 1997). $E_{W C}$ from the PM equation was $221 \mathrm{~mm}$ for $1996\left(6 \%\right.$ of $\left.P_{G}\right)$ and $287 \mathrm{~mm}$ for 1997 $\left(8 \%\right.$ of $\left.P_{G}\right)$. The rates of $E_{W C}$ from a wet canopy were $0.93 \sim 1.13 \mathrm{~mm} \mathrm{hr}^{-1}$ for 1996 and 1997. These values far exceeded $E_{W C}$ rates equivalent for the corresponding net radiation inputs $\left(0.1 \sim 0.11 \mathrm{~mm} \mathrm{hr}^{-1}\right)$, which provided only $\sim 10 \%$ of the required energy of $E_{W C}$. The discrepancy between $E_{W C}$ from these two methods was due to combined effect of energy advection and $g_{a}$ estimation. Because of unaccounted advection energy portion in $R_{N}$, a lower $R_{N}$ used in the PM equation produced a lesser $E_{W C}$. In addition, $g_{a}$ calculated by
Thom (1975) was much higher compared to that which was reversely solved from the PM equation, resulting in considerably lower $E_{W C}$.

Vernimmen et al. (2007) conducted the $E_{W C}$ measurements at a lowland evergreen rain forest (LERF) and two heath forests (HF; a tall HF and a stunted HF) in Central Kalimantan, Indonesia for one year (June 2002 to June 2003). Average tree height was about $40 \mathrm{~m}$ for LERF, about $20 \mathrm{~m}$ for the tall $\mathrm{HF}$ and about $15 \mathrm{~m}$ for the stunted HF. LAI was inferred from biomass estimation (i.e., leaf litterfall and specific leaf area) and canopy gap fraction was assessed from canopy image analysis using photographs vertically taken in July. $P_{G}$ was recorded above the canopy using a tipping bucket rain gauge. $P_{T}$ was measured using 20 rain gauges in each HF site and 18 gauges in LERF site and the gauges were relocated randomly to minimize the effect of spatial variability of the measurements. The measurements of $P_{S}$ was made for more than 20 trees using a stemflow collar consisting of a plastic hose fitted to the stem and the hoses drained into plastic containers. $L A I$ was 9.2, 6.0, and 4.8 for the LERF, the tall HF, and the stunted HF, respectively. Canopy gap fraction was similar at three sites, showing 0.13 for the LERF and the tall HF and 0.16 for the stunted HF. During the measurement period, $P_{G}$ amounted to $2,996 \mathrm{~mm}$, while $P_{T}$ was $2,481 \mathrm{~mm}\left(82.8 \%\right.$ of $\left.P_{G}\right)$ for the LERF, 2,670 $\mathrm{mm}(89.1 \%)$ for the tall $\mathrm{HF}$, and 2,298 $\mathrm{mm}(76.7 \%)$ for the stunted HF. The amounts of $P_{T}$ were not matched with the trend of $L A I$ and canopy gap fraction of each site. $P_{S}$ in the LERF, the tall HF and the stunted HF was $0.8 \%, 1.3 \%$, and $2.0 \%$ of $P_{G}$, indicating that $P_{S}$ was almost negligible. $E_{W C}$ derived by subtracting measured $P_{T}$ and $P_{S}$ from $P_{G}$ was $490 \mathrm{~mm}\left(16.4 \%\right.$ of $\left.P_{G}\right)$ for the LERF, $286 \mathrm{~mm}(9.6 \%)$ for the tall HF, and $637 \mathrm{~mm}$ $(21.3 \%)$ for the stunted HF. These variations were attributed by those in $P_{T}$ rather than $P_{S}$.

The values of $E_{W C}$ was much larger than the estimated $E_{W C}$ from the model of Gash et al. (1995), which calculated $E_{W C}$ using the PM equation and $g_{a}$ based on the method of Thom (1975). For example, $E_{W C}$ at the stunted HF was $1.4 \mathrm{~mm} \mathrm{hr}^{-1}$, whereas the estimated $E_{W C}$ from the model was $0.06 \mathrm{~mm} \mathrm{hr}^{-1}$. Vernimmen et al. (2007) suggested that such difference resulted from considerable underestimation of $P_{T}$, which was obtained using 20 rain gauges in this study. They emphasized the importance of $P_{T}$ sampling schemes in tropical forest especially when water balance method was used to estimate $E_{W C}$. 


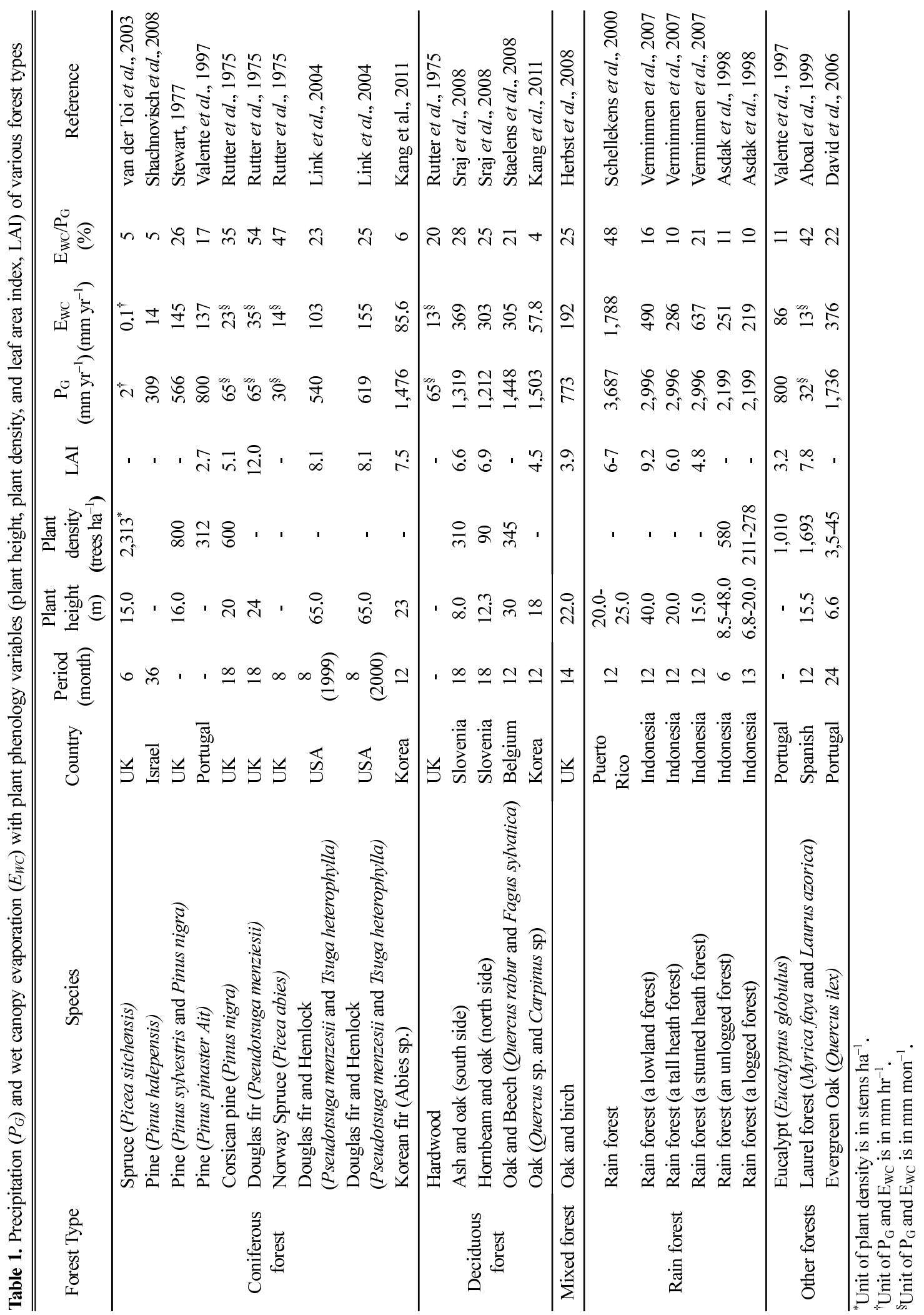


Asdak et al. (1998) conducted the measurement of $E_{W C}$ over rainforests (i.e., a logged forest from November 1993 to April 1994 and an unlogged forest from June 1994 to June 1995) in Central Kalimantan, Indonesia to assess the influence of canopy structure on $E_{W C}$. The height of the trees in the unlogged forest varied between 8.5 to $48.0 \mathrm{~m}$, while that in the logged forest ranged from $6.8 \mathrm{~m}$ to $20.0 \mathrm{~m}$. The density of the forest was about 580 trees $\mathrm{ha}^{-1}$ for the unlogged forest and 211 278 trees ha ${ }^{-1}$ for the logged forest. $E_{W C}$ was estimated from the water balance method. $P_{G}$ was measured using one tipping bucket rain gauge for the unlogged forest and three tipping bucket rain gauges for the logged forest. In order to measure $P_{T}, 50$ gauges were equally distributed under the canopy (i.e., a $100 \times$ $40 \mathrm{~m}$ plot along with five parallel transects) in the unlogged forest. In the logged forest, 55 gauges were installed according to the proportion of canopy cover and 15 tipping bucket rain gauges were randomly located in fixed positions. $P_{S}$ was measured on 16 trees in different tree sizes for the unlogged forest and 20 trees for the logged forest.

The estimates of $P_{T}, P_{S}$, and $E_{W C}$ were $1,918 \mathrm{~mm}$ (87.2\% of $\left.P_{G}, 2,199 \mathrm{~mm}\right), 30 \mathrm{~mm}(1.4 \%)$, and $251 \mathrm{~mm}$ (11.4\%) for the unlogged forest and 3,334 $\mathrm{mm}$ (94\% of $\left.P_{G} 3,563 \mathrm{~mm}\right), 9.6 \mathrm{~mm}(0.3 \%)$, and $219 \mathrm{~mm}(6.2 \%)$ for the logged forest, respectively. As expected, the closed canopy of the unlogged forest had higher values of $P_{S}$ and $E_{W C}$ compared to the partially closed canopy of the logged forest, indicating the influence of stand structure on the water budget components. The spatial variability of $P_{T}$ was statistically significant due to variation in stand structure, resulting in $P_{T}$ varying from 45 to $105 \%$ of $P_{G}$. Because there were more trees in the unlogged forest than the logged forest, $P_{S}$ in the unlogged forest was higher than the logged forest. The difference in stand structure (e.g., canopy closeness) affects the canopy gap faction and canopy storage capacity and aerodynamic properties.

\section{DISCUSSION}

\subsection{Precipitation, throughfall, and stemflow}

$E_{W C}$ is the difference between $P_{G}$ and $P_{T}$ and errors in estimation of both can hamper an accurate estimation in $E_{W C}$. Possible errors relating to $P_{G}$ measurement is a wind-induced underestimation and/or an overestimation by blow-in rain drops from the nearby higher tree crowns. And spatial variability of $P_{G}$ can be possible over a short distance during a high-intensity stormy rain period. It is recommended to use a rain gauge with a wind shield to reduce the possible loss in rainfall (Lindorth, 1991) and to conduct precipitation measurement more than one position to have a representative of a measurement site.

Because canopy structure and rainfall intensity affect $P_{T}$ and $P_{S}$ (e.g., Sraj et al., 2008), they considerably vary in most forests. Canopy characteristics include crown size, leaf shape and orientation, branch angle, bark type, and canopy gaps whereas rainfall characteristics are continuity, intensity, and the angle of rainfall. In order to overcome high spatial variability of $P_{T}$, it has been recommended to use a combination of fixed and randomly roving rain gauges (e.g., Lloyd and Marques, 1988; Sraj et al., 2008). In contrast to the careful measurements of $P_{T}, P_{S}$ has received little attention in many studies under a premise that the ratio of $P_{S}$ to $P_{G}$ is considerably small ( $<3 \%$ of $P_{G}$; Asdak et al., 1998; Schellekens et al., 2000). Asdak et al. (1998) reported that $P_{S}$ was $0.3 \sim 1.4 \%$ of $P_{G}$ (see above). However, $P_{S}$ can be much larger (e.g., $9 \%$ of $P_{G}$ for a coniferous forest, Crockford and Richardson, 1990). The influence of canopy structure on $P_{S}$ can be negligible (e.g., no variation in $P_{S}$ at different canopy characteristics in a mixed deciduous forest; Sraj et al., 2008). These results indicate that variation of $P_{S}$ is site-specific and careful methodological approach is required to make reliable measurement of $P_{S}$.

\subsection{Sensible heat flux and heat storage}

An attractive aspect of temperature variance method is that temperature measurements from a simple, single-level sensor can provide a reliable estimation of $H$ under the unstable atmospheric conditions (Tillman, 1972; De Bruin et al., 1993). Despite the stable atmospheric conditions during rainy period, Schellenkens et al. (2000) applied this method to estimate $H$ (Eq. 14 and 15) and consequently $E_{W C}$ applying the energy balance method (Eq. 12). According to De Bruin and Hartogensis (2005), $H$ can be derived fairly accurately from the variance method under stable atmospheric conditions which are common for most rainy days. They used 2.3 for $\mathrm{C}_{1}$ and 2.5 for $\mathrm{C}_{2}$ as the empirical constants in Eq. 14.

Eddy covariance method employs a 3-dimensional sonic anemometer to measure $H$, whose function is sensitive to water drops. The data during rainfall need to be screened and the performance of the anemometer 
needs to be verified before the analysis. Kang et al. (2010 and 2011) presented the data filtering process collected from the anemometer (e.g., CSAT3, Campbell Sci. USA) by comparing the data from the anemometer, wetness sensors, and precipitation. The performance of the anemometer was relatively independent on rain intensity and quickly recovered after rain stopped. As indicated above, the quality of $H$ measurements can be evaluated from a linear relationship between $\sigma_{w}$ and $u^{*}$ based on the Monin-Obukhov similarity theory (e.g., van der Toi et al., 2003 and Herbst et al., 2008) and from a spectral analysis (e.g., Gash et $a l ., 1999$ ). For an accurate measurement of $H$, scrutiny on the data prior to the data analysis is strongly recommended.

Estimation of $S$ is one of the challenges in calculating $E_{W C}$ due to the difficulty and the least accuracy, and is often considered insignificant due to its small variability for periods longer than a day compared to other energy components (Oliphant et al., 2004). Finnigan (2006), on the other hand, suggested that the variation in $S$ over short periods such as an hour can be substantial and can cause larger imbalance in energy balance closure. When an attempt is made to determine $S$, widely varying methods and definitions add more complexity (Oliphant et al., 2004). Based on the previous studies to estimate $E_{W C}$ including $S$ in the energy balance method, $S$ is small because temperature and humidity changes are small and $R_{N}$ is low when the canopy is wet. Thus, $R_{N}$ alone is a close approximation to $A$ to estimate $E_{W C}$. van der Tol et al. (2003) reported that $E_{W C}$ was not sensitive to errors induced from $S$, showing almost no change in $E_{W C}$ regardless of the inclusion of or exclusion of $S$. However, these results may not be taken as a general case because the magnitudes of $S$ can be site-specific.

\subsection{Aerodynamic conductance}

Estimation of $E_{W C}$ using the PM equation is sensitive to the value of $g_{a}$ (Gash et al., 1980 and 1999). In most cases, roughness length for $g_{a}$ estimation considers only momentum transfer $\left(\mathrm{z}_{0, M}\right)$. A few studies suggest calculating $g_{a}$ by taking an account of different transfer mechanisms of heat and water vapor $\left(\mathrm{z}_{0, H}\right)$ during rainfall (e.g., Klaassen et al., 1998). According to Gash et al. (1999), $g_{a}$ estimation considering only $\mathrm{z}_{0, \mathrm{M}}$ had a better result in determining $E_{W C}$ than $g_{a}$ estimation by considering both $\mathrm{z}_{0, M}$ and $\mathrm{z}_{0, H}$. Another commonly used method to estimate $g_{a}$ (Eq. 9) illustrated dissimilar results in calculating $E_{W C}$. For example, Herbst et al. (2008) showed good agreement of $E_{W C}$ from the water balance method with that from the PM equation with $g_{a}$ obtained by Eq. 9. However, Schellekens et al. (2000) showed poor agreement between the measured and estimated $E_{W C}$. Estimation of $E_{W C}$ may not be as sensitive to $g_{a}$ as it is suggested by Gash et al. (1980 and 1999 ). $E_{W C}$ can be derived fairly accurately from different methods of $g_{a}$ estimation.

\subsection{Advection of sensible heat}

$E_{W C}$ calculated from the PM equation does not include the possible influence of heat advection unlike the energy balance method that encompasses it as presented in sensible heat flux. Stewart (1977) and Schellekens et al. (2000) illustrated that excess energy consumed in $E_{W C}$, compared to net radiation, was due to additional advection energy by sensible heat. Kang et al. (2010) presented that consideration of the heat advection in a model performance (e.g., variable infiltration capacity (VIC) land surface model) produced more realistic $E_{W C}$ than a gap-filling method (e.g., a modified look-up table method), resulting in a substantially increased contribution of $E_{W C}$ to the annual ET. Their results suggest that the comparison of $E_{W C}$ estimated from the PM and energy balance methods may not necessarily be equivalent when heat advection occurs, and thus an appropriate method of estimating $E_{W C}$ should be carefully considered to fill the gap of the missing $E_{W C}$ data.

\section{SUMMARY}

In this review, wet canopy evaporation from diverse forest types such as deciduous forest, coniferous forest, mixed forest, and rain forest was summarized. The three most commonly used methods are water balance, energy balance, and the Penman-Monteith methods. An accurate estimation of wet canopy evaporation requires reliable measurements of precipitation, throughfall, and stemflow for water balance method, and of sensible heat flux and heat storage for energy balance method, and of aerodynamic conductance and consideration of sensible heat advection for the Penman-Monteith method. In order to account for each method's shortcomings and obtain accurate estimation of wet canopy evaporation, a combination of different methods is preferable. Because the amount of wet canopy evaporation mostly depends on canopy characteristics and 
meteorological conditions, it is difficult to draw a general conclusion on wet canopy evaporation from particular forest types and meteorological conditions.

Seasonal and annual wet canopy evaporation in forests can be significant due to an extensive cover of forests and frequent rainfalls under the influence of the Asian monsoon in Korea. The measurements of wet canopy evaporation, however, are in paucity. KoFlux, the Korean regional flux measurement network, has been conducting the measurements of evapotranspiration using the eddy covariance system along with hydrometeorological measurements at major forest types. This allows to assess wet canopy evaporation using the combination of multiple methods and to provide the quality data on wet canopy evaporation. Considering the important contribution of wet canopy evaporation to ET, it is essential to scrutinize the role of wet canopy evaporation in the Korean forests under the monsoon climate. It is strongly recommended not only to conduct the measurements of wet canopy evaporation but also to utilize the existing infrastructure (e.g., KoFlux) accompanied with accumulated data for further analysis to provide insights on the role of wet canopy evaporation on hydrological cycles in Korea.

\section{적 요}

산림에서의 차단강수증발 $\left(E_{W C}\right)$ 은 증발산과 강수에 중 요한 기여를 한다. 따라서, 산림에서의 수문순환을 이 해하기 위해서는 정확한 $E_{W C}$ 를 산정하는 것이 중요하 다. 본 고찰에서는 $E_{W C}$ 의 측정방법을 소개하고, 선행 연구에서 보고된 산림형태(예를 들면, 활엽수림, 침엽수 림, 혼효림, 열대림)에 따른 $E_{W C}$ 값과 측정시 고려해 야 할 사항에 대하여 논의하였다. 전형적인 $E_{W C}$ 측정 에는 물 수지, 에너지 수지 및 Penman-Monteith 방 법이 있다. 전반적으로, $E_{W C}$ 는 강수량의 $5 \sim 54 \%$ 를 차 지하였으며, 같은 산림형태내에서도 $E_{W C}$ 의 강수량에 대한 기여도는 큰 변동을 보였다. 이러한 변동에는 강 수강도, 기상조건, 군락 구조 특성이 영향을 미치는 것 으로 나타났다. 따라서 특정 산림형태에서의 $E_{W C}$ 의 강 수량에 대한 기여도를 정량화하는 것은 어려울 것으로 판단된다. 관측시 발생하는 오차는 $E_{W C}$ 정량화의 불확 실성을 증대 시킨다. 물수지 방법의 경우, 풍속의 영향 을 받는 강수 관측과 군락 구조의 공간적 비균질성의 영향을 받는 수관통과우 등의 관측 오차를 들 수 있 다. 에너지 수지 방법의 경우에는 현열 플럭스와 열저 류항의 관측이 주요 오차의 원인이 되며, Penman-
Monteith 방법은 공기전도도와 현열의 이류 추정에서 발생하는 오차에 주의를 기울여야 한다. 각 측정방법의 오차를 최소화하고 신뢰할 수 있는 $E_{W C}$ 를 얻기위해서 는 수문학적 방법과 미기상학적 방법, 즉 물 수지와 에너지 수지 방법을 함께 사용하는 것이 바람직하다.

\section{ACKNOWLEDGEMENTS}

This study is supported by a grant (Code: 1-8-3) from Sustainable Water Resources Research Center of $21^{\text {st }}$ Century Frontier Research Program, the Long-term Ecological Study and Monitoring of Forest Ecosystem Project of Korea Forest Research Institute, the A3 Foresight Program from National Research Foundation of Korea and Korea Meteorological Administration. I thank the three anonymous reviewers for their constructive comments and suggestions.

\section{REFERENCES}

Asdak, C., P. G. Jarvis, and P. V. Gardingen, 1998: Evaporation of intercepted precipitation based on an energy balance in unlogged and logged forest areas of central Kalimantan, Indonesia. Agricultural and Forest Meteorology 92, 173-180.

Crockford, R. H., and D. P. Richardson, 2000: Partitioning of rainfall into throughfall, stemflow and interception: effect of forest type, ground cover and climate. Hydrological Processes 14, 2903-2920.

Davis, T. S., J. H. C. Gash, F. Valente, J. S. Pereira, M. I. Ferreira, and J. S. David, 2006: Rainfall interception by an isolated evergreen oak tree in a Mediterranean savannah. Hydroogical Processes 20, 2713-2726.

De Bruin, H. A. R., and O. K. Hartogensis, 2005: Variance method to determine fluxes of momentum and sensible heat in the stable atmospheric surface layer. BoundaryLayer Meteorology 116, 385-392.

De Bruin, H. A. R., W., Kohsiek, and B. J. J. M., van den Hurk, 1993: A Verification of Some Methods to Determine the Fluxes of Momentum, Sensible Heat and Water Vapour Using Standard Deviation and Structure Parameter of Scalar Meteorological Quantities. Boundary-Layer Meteorology 63, 231-257.

Dingman, S., 2002: Physical Hydrology. Prentice Hall, Upper Saddle River. 646p.

Finnigan, J., 2006: The storage term in eddy flux calculations. Agricultural and Forest Meteorology 136, 108-113.

Gash, J. H. C., 1979: An analytical model of rainfall interception by forests. Quarterly Journal of the Royal Meteorological Society 105, 43-55.

Gash, J. H. C., C. R. Lloyd, and G. Lachaud, 1995: Estimating sparse forest rainfall interception with an analyt- 
ical model. Journal of Hydrology 170, 79-86.

Gash, J. H. C., F. Valente, and J. S. David, 1999: Estimates and measurements of evaporation from wet, sparse pine forest in Portugal. Agricultural and Forest Meteorology 94, 149-158.

Gash, J. H. C., I. R. Wright, and C. R. Lloyd, 1980: Comparative estimates of interception loss from three coniferous forests in Great Britain. Journal of Hydrology 48, 89-105.

Herbst, M., P. T. W. Rosier, D. D. McNeil, R. J. Harding, and D. J. Gowing, 2008: Seasonal variability of interception evaporation from the canopy of a mixed deciduous forest. Agricultural and Forest Meteorology 148, 16551667.

Herrington, L.P., 1969: On temperature and heat flow in tree stems. Yale University, School of Forestry and Envornmental Bulletin, 73.

Horton, R. E., 1919: Rainfall interception. U.S. Monthly Weather Review. 47.

Kang, M., H. Kwon, J.-H. Lim, and J. Kim, 2010: On estimating wet canopy evaporation from deciduous forest in Korea. The International Conference of $2^{\text {nd }}$ Hydrology delivers Earth System Science to Society, The University of Tokyo, Japan, June 22-25, 2010.

Kang, M., H. Kwon, J.-H. Lim, and J. Kim, 2010: On estimating wet canopy evaporation from deciduous and coniferous forest in Korea. Journal of Hydrological Metrology (in revision).

Kim, K. B., and B. M. Woo, 1988: Study on rainfall interception loss from canopy in forest (I). Journal of Korean Forest Society 77, 331-337. (in Korean with English abstract)

Kim, K. H., J. Jun, J. Yoo, and Y. Jeong, 2005: Troughfall, stemflow and interception loss of the natural old-growth deciduous and planted young coniferous in Gwangneung and the rehabilitated young minxed Forest in Yangju, Gyeonggido(I) - with a special reference on the results of measurement-. Journal of Korean Forest Society 94, 488-495. (in Korean with English abstract)

Klassen, W., F. Bosveld, and E. de Water, 1998: Water storage and evaporation as constituents of rainfall interception. Journal of Hydrology 212-213, 36-50.

Lankreijer, H. J. M., M. J. Hendriks, and W. Klaassen, 1993: A comparison of models simulating rainfall interception of forests. Agricultural and Forest Meteorology 64, 187199.

Lee, D. K., G. T., Kim, K. Y. Joo, Y. S. Kim, 1997: Throughfall, stemfall and rainfall interception loss in Pinus koraiensis Sieb. et Zucc., Larix leptolepis (Sieb. et Zucc.) Gordon and Quercus species stand at Kwangju-Gun, Kyunggido. Journal of Korean Forest Society 86, 200-207. (in Korean with English abstract)

Lindroth, A., 1991: Reduced Loss in Precipitation Measurements Using a New Wind Shield for Raingages.
Journal of Atmospheric and Oceanic Technology 8, 444451.

Lloyd, C. R., and A., De O. Marques, 1988: Spatial variability of throughfall and stemflow measurements in Amazonian rainforest. Agricultural and Forest Meteorology 42, 63-73.

Johnson, R., 1990: The interception, throughfall and stemflow in a forest in highland Scotland and the comparison with other upland forests in the UK. Journal of Hydrology 118, 281-287.

Min, H. J., and B. M. Woo, 1995: Throughfall, stemflow, and interception loss at Pinus taeda and Pinus densiflora stands. Journal of Korean Forest Society 84, 502-516. (in Korean with English abstract)

Michiles, A. A. S., and R. Gielow, 2008: Above-ground thermal energy storage rates, trunk heat fluxes and surface energy balance in a central Amazonian rainforest. Agricultural and Forest Meteorology 148, 917-930.

Monteith, J. L., 1965: Evaporation and environment. Symposia Society for Experimental Biology 19, 205-224.

Muzylo, A., P. Llorens, F. Valente, J. J. Keizer, F. Domingo, and J. H. C. Gash, 2009: A review of rainfall interception modeling. Journal of Hydrology 370, 191-208.

Oliphant, A. J., C. S. B. Grimmond, H. N. Zutter, H. P. Schmid, H.-B. Su, S. L. Scott, B. Offerle, J. C. Randolph, and J. Ehman, 2004: Heat storage and energy balance fluxes for a temperate deciduous forest. Agricultural and Forest Meteorology 126, 185-201.

Pypker, G. T., B. J. Bond, T. E. Link, D. Marks, and M. H. Unsworth, 2005: The importance of canopy structure in controlling the interception loss of rainfall: Examples from a young and an old-growth Douglas-fir forest. Agricultural and Forest Meteorology 130, 113-129.

Rutter, A. J., A. J. Morton, and P. C. Robins, 1975: A predictive model of rainfall interception in forest. II. Generalization of the model and comparison with observations in some coniferous and hardwood stands. Journal of Applied Ecology 12, 367-380.

Schellekens, J., L. A. Bruijnzeel, F. N. Scatena, N.J. Bink, and F. Holwerda, 2000: Evaporation from a tropical rain forest, Luquillo Experimental Forest, eastern Puerto Rico. Water Resources Research 36, 2183-2196.

Shachnovich, Y., P. R. Berliner, and P. Bar, 2008: Rainfall interception and spatial distribution of throughfall in a pine forest planted in an arid zone. Journal of Hydrology 349, 168-177.

Silberstein, R., A. Held, T. Hatton, N. Viney, and M. Sivapalan, 2001: Energy balance of a natural jarrah (Eucalyptus marginata) forest in Western Australia: measurements during the spring and summer. Agricultural and Forest Meteorology 109, 79-104.

Singh, R. P., 1987: Rainfall interception by Pinus Wallichiana plantation in temperate region of Himachal Pradesh, India. Indian Forester 113, 559-566. 
Sraj, M., M. Brilly, and M. Mikos, 2008: Rainfall interception by two deciduous Mediterranean forests of contrasting stature in Slovenia. Agricultural and Forest Meteorology 148, 121-134.

Staelens, J., A. De Schrijver, K. Verheyen, and N. E. C. Verhoest, 2008: Rainfall partitioning into throughfall, stemflow, and interception within a single beech (Fagus sylvatica L.) canopy: influence of foliation, rain event characteristics, and meteorology. Hydrological Processes 22, 33-45.

Stewart, J. B., 1977: Evaporation from the wet canopy of a pine forest. Water Resources Research 13, 915-921.

Tillman, J. E., 1972: The indirect determination of stability, heat and momentum fluxes in the atmospheric boundary layer from simple scalar variables during dry unstable conditions. Journal of Applied Meteorology 11, 783-792.

Thom, A. S., 1975: Momentum, mass and heat exchange of plant communities. In: Monteith, J. L. (Ed.), Vegetation and the Atmosphere, Principles, Academic Press, London, UK pp 57-109.

Valente, F., J. S., David, and J. H. C. Gash, 1997: Model- ling interception loss for two sparse eucalypt and pine forests in central Portugal using reformulated Rutter and Gash analytical models. Journal of Hydrology 190, 141162.

van der Tol, C., J. H. C. Gash, S. J. Grant, D. D. McNeil, and M. Robinson, 2003: Average wet canopy evaporation for a Sitka spruce forest derived using the eddy correlation-energy balance technique. Journal of Hydrology 276, 12-19.

Vugts, H. F., M. J. Waterloo, F. J. Beekman, K. F. Frumau, and L. A. Bruijnzeel, 1993: The temperature variance method, a powerful tool in the estimation of actual evapotranspiration rates. Hydrology of Warm Humid Regions, Proceedings of the Yokohama Symposium, International Association of Hydrological Sciences Publication 216, 251-260.

Vermimmen, R. R. E., L. A. Bruijnzeel, A. Romdoni, and J. Proctor, 2007: Rainfall interception in three contrasting lowland rain forest types in Central Kalimantan, Indonesia. Journal of Hydrology 340, 217-232. 